\title{
Dan SALAGA*
}

\section{ASCENSIUNEA POLITICĂ ȘI ORGANIZAREA PARTIDULUI COMUNIST DIN ROMÂNIA PÂNĂ LA PRELUAREA GUVERNĂRII (6 MARTIE 1945)}

\author{
THE POLITICAL EMERGENCE AND ORGANIZATION OF THE \\ COMMUNIST PARTY IN ROMANIA UNTIL ITS TAKE OVER OF \\ GOVERNMENT (6 MARCH 1945)
}

\begin{abstract}
The author aims to reconstruct the way in which the Communist Party of Romania prepared to take over the government on 6 March 1945. He highlights strategies for attracting new members, creating support organisations, infiltrating trade union, forcefully seizing power at the local level. The author discusses a series of archival documents that supplement the information on the number of members and the organization of the Communist Party in the first months after the events of August 1944.
\end{abstract}

Keywords: Communist Party, National Democratic Bloc, Ana Pauker, Gheorghe Gheorghiu-Dej, Sovietization, 6 March 1945

Participarea PCdR la alianța Blocului Naţional Democrat și semnarea de către Lucrețiu Pătrășcanu, Petre Constantinescu Iași și Vasile Bâgu a protocolului BND, la 20 iunie 1944, ca și exponenți ai partidului comunist va impune, implicit, recunoașterea acestuia ca un partener politic. ${ }^{1} \mathrm{Cu}$ toate acestea, chiar Lucrețiu Pătrășcanu recunoștea, într-o ședință a BND din 27 iunie 1944, faptul că PCdR „,neavând o existență legală de atâția ani, și cu o buna parte a cadrelor sale în închisori sau lagăre-nu dispune încă de o organizare serioasă și că abia acum își va putea-o face". ${ }^{2}$

\footnotetext{
*Consiliul Național pentru Studierea Arhivelor Securității, București;dansalaga@yahoo.com. ${ }^{1}$ Gheorghe Onișoru, Alianțe și confruntări între partidele politice din România (19441947), Fundaţia Academia Civică, 1996, p.115.

2 Ioan Hudiță, Jurnal politic. 1 ianuarie-24 august 1944, Ed. Roza Vânturilor, București,1997, p 233.
} 
Chiar dacă nu se va schimba prea mult situația și, cel puțin prin numărul de membri, partidul comunist continua să fie o grupare minoră, el se va afirma destul de agresiv pe eșichierul politic românesc. Pe 30 august 1944 are loc intrarea oficială în București a Armatei Sovietice, iar comuniștii, împreuna cu reprezentanții PSD, vor organiza un miting în Piaţa Universității. ${ }^{3}$

Pentru a simula oarecum o organizare în masă și a se erija în reprezentantul unei cât mai largi pături sociale, Partidul Comunist din România va dispune de aportul unor formațiuni politice cum ar fi Uniunea Patrioților (Uniunea Patriotică), Frontul Plugarilor sau Partidul Socialist-Țărănesc.

Astfel, la 2 septembrie 1944, Partidul Socialist Țărănesc, condus de Mihail Ralea publica în presa comunistă manifestul „Chemare către țară”, în care se afirma, printre altele: „strânși uniţi în mănunchiul promițător, de generoase nădejdi, al Grupului Patriotic Antihitlerist, împreună cu Partidul Comunist, cu Uniunea Patriotică, cu Frontul Plugarilor și Partidul Social Democrat, vom lupta până la izbânda finală". ${ }^{4}$

La 6 septembrie 1944 se va constitui Grupul Patriotic Antihitlerist, compus din PCdR, PSD, Uniunea Patrioților, Partidul Socialist Țărănesc și Frontul Plugarilor. Astfel, comuniștii puteau să declare că funcționarea Blocului Naţional Democrat nu mai părea de actualitate, fiind necesar un „Front Naţional Unic”, care să mai cuprindă și alte formațiuni politice, aliniate PCdR-ului și care să susțină politica acestuia. ${ }^{5}$

La 18 septembrie, o altă „,formațiune politică democratică”, respectiv Uniunea Patrioților, a lansat o „Chemare către întreaga țară”, în care , printre altele, se definește ca fiind: „,o organizație de luptă a maselor populare, deschisă tuturor categoriilor sociale şi tuturor celor care vor să contribuie la eliberarea completă a țării de rămășițele hitleriste și la instaurarea drepturilor cetățenești. Ea nu este un partid politic, ci o mișcare largă de concentrare a tuturor forțelor active antihitleriste și de creare a unui front patriotic național". ${ }^{6}$

Trebuie să menționăm că o grupare politică agresivă, ce țintea preluarea puterii politice sau în limbajul politic actual ,ajungerea la guvernare”, avea nevoie și de o presă pe măsură. La 24 august 1944, apare deja primul număr în legalitate al

\footnotetext{
${ }^{3}$ Stelian Neagoe, Istoria politică a României 1944-1947,Ed.Noua Alternativă, București, 1996, p.47.

${ }^{4}$ România Liberă, nr.17 din 2 septembrie 1944, în Stelian Neagoe, op.cit.,p.52.

${ }^{5}$ România Liberă ,nr. 23 din 6 septembrie 1944, în Stelian Neagoe, op.cit.,p.53.

${ }^{6}$ Stelian Neagoe, op.cit.,p. 78.
} 
ziarului România Liberă, ${ }^{7}$ iar la 21 septembrie, același an primul număr al ziarului Scânteia. ${ }^{8}$

Un moment important pentru comuniști îl va reprezenta semnarea, la 12 septembrie 1944, a Convenției de Armistițiu cu Națiunile Unite la Moscova. De acum încolo, cel mai mare militant pentru aplicarea prevederilor convenţiei va fi PCdR împreuna cu celelalte „organizaţii politice democratice”. ${ }^{9}$ Ana Pauker, liderul comunist venit împreună cu tancurile sovietice remarca „, atitudinea extrem de generoasă a Uniunii Sovietice față de România". ${ }^{10}$

Prima ședință organizată de către conducerea PCdR în legalitate va fi ședința activului central din zilele 23-24 septembrie 1944 ce avea pe ordinea de zi discutarea "Proiectului de Platformă pentru constituirea Frontului Naţional Democrat”. ${ }^{11}$ În prim plan apar liderii de facto ai partidului, anume Ana Pauker şi Gheorghe Gheorghiu Dej.

Conform celor discutate în cadrul ședinței, s-a acreditat ideea că Blocul Național Democrat nu mai este o formulă viabilă, la guvernare trebuind să participe și formațiunile satelit ale comuniștilor, asta însemnând o mai mare reprezentabilitate în guvern, Partidul Național Țărănesc și Partidul Naţional Liberal nemaifiind parteneri de dialog viabili, având în componența lor elemente fasciste ce trebuiau epurate, sau promovând asemenea elemente. Alexandru Drăghici, prezent și el la discuții, concluziona că: „se impune schimbarea întregului aparat de Stat şi al Guvernului". ${ }^{12}$ Gheorghe Maurer solicita ca Platforma Program a FND să cuprindă „curăţirea” Baroului, Corpului inginerilor, a medicilor de elemente fasciste. ${ }^{13}$

Esența problemei o exemplifică Gheorghe Gheorghiu Dej, care afirmă că e un moment important pentru partid, care poate deveni „,forța principală politică în

\footnotetext{
${ }^{7}$ Ibidem, p. 35 .

${ }^{8}$ Ibidem, p. 80.

${ }^{9}$ Un apel plin de atașament adresa populației conducerea PCdR, ca urmare a semnării Convenției de Armistițiu: „Împlinirea riguroasă a condițiilor de armistițiu este piatra hotărâtă de despărțire între vechea politică antinațională, politică de vrășmășie împotriva Uniunii Sovietice şi noua politică de prietenie cu Uniunea Sovietică. Pentru binele patriei și al națiunii, datoria fiecărui patriot român este să ducă lupta necruțătoare contra oricui s-ar opune în calea împlinirii conștiincioase a stipulațiilor prevăzute de acordul de armistițiu." (Marin Radu Mocanu, coordonator, România și Armistițiul cu Națiunile Unite. Documente, vol.II, Arhivele Statului din România, București, 1995, p.59).

${ }^{10}$ Scânteia, nr. 59, din 18 noiembrie 1944, în Victor Frunză, Istoria Stalinismului în România, Ed. Humanitas, București, 1990, p.164.

${ }^{11}$ Coord. Radu Ciuceanu, Corneliu Mihai Lungu, responsabil de volum Florin Constantiniu, Stenogramele Ședințelor Conducerii P.C.R.. 23 septembrie-26 martie 1945, Institutul Național pentru Studiul Totalitarismului, Arhivele Naționale ale României (vezi și Arhivele Naționale Istorice Centrale (ANIC), Fond CC al PCR, Cancelarie, Dosar 10/1944).

12 Ibidem, p. 21.

${ }^{13}$ Ibidem, p. 23.
} 
țara româneasca" ${ }^{14}$ Liderul comunist ataca vehement partidele istorice care se făceau vinovate de înlăturarea lui Carol al II-lea și instituirea regimului antonescian $^{15}$

Ținând cont de toate acestea, la o lună de la intrarea în legalitate, Gheorghiu Dej se lăuda că, deja ,există un proces puternic de deplasare spre stânga”, partidul fiind ,asaltat de numeroși solicitanți”. Dar, trebuia sa existe o selecție a membrilor, pentru a nu permite „elementelor mici burgheze” să fie în număr prea mare. Baza numerică a Partidului Comunist din România trebuia să o reprezinte clasa muncitoare organizată în sindicate puternice, controlate bineînțeles de către partid. ${ }^{16}$ Lupta politică, ,revoluționară”, trebuia să fie susținută în stradă cu mitinguri si demonstrații. În consecință, la 24 septembrie 1944, are loc, pe stadionul A.N.E.F. din București, primul mare miting al sindicatelor controlate de comuniști, în care, Gheorghiu Dej, în cuvântarea sa, cere demisia guvernului Sănătescu și formarea unui guvern în care să intre partidele din Blocul Naţional Democrat, dar și alte formațiuni politice aflate sub influența partidului comunist: Uniunea Patrioților, Frontul Plugarilor și Partidul Socialist Țărănesc, afirmând că: „legionarii și elementele reacționare antonesciene sunt principalul pericol intern (...) Atâta vreme cât aparatul de stat, instituțiile publice și întreprinderile industriale n-au fost curățate de acești dușmani, suntem obligați să nu încetăm o clipă lupta începută.(...) Această acțiune de curățire nu poate fi făcută de către acest guvern (...) Numai un guvern care să reprezinte cele mai largi pături muncitoare de la orașe și sate, toate forțele democratice ale țării, poate rezolva sarcinile actuale de interes vital pentru poporul

\footnotetext{
$\overline{14}$ „Partidul stă în fața unei cotituri politice de mare importanță pentru viitorul clasei muncitoare, pentru viitorul poporului romăn, importantă în primul rând penru viitorul cauzei politice Partidului nostru, dacă această cotitură va fi însuşită de noi și aplicată just în practică, ea poate intradevăr să facă Partidul nostru să devină ceea ce cu toții dorim, factorul politic, forța principală politică în țara românească" (Ibidem, p. 64).

15 „Ei bine, tovi, alungarea lui Carol din țară și aducerea regimului lui Antonescu a fost hotărâtă împreună cu Maniu, cu Brătianu, cu responsabilii clasei dominante. Pentru că, oricâte divergențe ar exista în sânul cercurilor burgheze, totuși, pentru anumite lucruri, ei fac front comun, atunci când interesele lor de clasă sunt amenințate, ei se sprijină reciproc. Cum ne-am putea explica altfel că conducătorii partidelor Național Țărănesc și Naţional Liberal au dezarmat așa ușor, că s-au plecat în fața lui Antonescu ca niște mielușei și 1-au lăsat pe Antonescu să decapiteze și restul de libertăți democratice care rămăsese poporului român și clasei muncitoare" (Ibidem, p.66).

16 ,Dacă este să întărim Partidul nostru, apoi în primul rând să ne orientăm spre fabrici, spre sindicate, acolo găsim acel rezervor uriaș, de unde Partidul nostru poate trage forțe noi, pentru a-și întări poziția sa” (Ibidem, p.71).
} 
român."17 Așadar, Gheorghiu Dej susține, conform principiului marxism leninismului. că „,muncitorimea din sindicate are dreptul și trebuie să facă politică. ${ }^{18}$

La 12 octombrie 1944 se constituie Consiliul FND, care avea în componență, între alții pe Lucrețiu Pătrășcanu și Gheorghiu Dej de la comuniști, Constantin Titel Petrescu și Lothar Rădăceanu de la Partidul Social Democrat. Iuliu Maniu și Constantin Brătianu, liderii Partidului Naţional Țărănesc și Partidului Național Liberal, erau și ei invitați să facă parte din FND, dar cei doi s-au declarat împotriva intrării în guvern a sateliților PCdR. Prin urmare, în cadrul ședinței conducerii Blocului Naţional Democrat, Lucrețiu Pătrășcanu și Constantin Titel Petrescu au anunțat demisia din BND. ${ }^{19}$

Astfel, prin influența pe care o avea asupra celorlalte organizații şi beneficiind de sprijinul nemijlocit al Moscovei, PSD fiind singurul partid în adevăratul sens al cuvântului, PCdR va fi, de facto, liderul FND, prin care trebuia atins obiectivul imediat, și anume participarea la guvernare. Iar, într-o primă fază, FND, care se prezenta ca „o coaliție de partide și organizații” trebuia să obțină un număr important de miniștri în viitorul guvern iar mai apoi preia guvernarea fără reprezentanți ai PNL sau PNȚ. ${ }^{20}$

La 30 noiembrie 1944, Partidul Socialist Țărănesc, condus de Mihail Ralea, va fi integrat Frontului Plugarilor.

Dacă autoritatea centrală trebuia schimbată de către rege, în teritoriu lucrurile au stat cu totul diferit. Astfel, reprezentanții FND din teritoriu încep să se manifeste independent de soluțiile legale și încep să înlocuiască prefecții de județe, sau primarii din orașele mari și nu numai. O astfel de iniţiativă va fi luată la Galați, la 28 octombrie 1944, unde demonstranții care participau la o manifestație girată de FND fiind „cetățeni ai orașului Galați, reprezentând toate categoriile sociale, în frunte cu miile de muncitori" vor încheia două procese verbale, prin care erau înlocuiți primarul Galațiului, respectiv prefectul județului Covurlui cu reprezentanți ai FND. ${ }^{21}$

\footnotetext{
${ }^{17}$ Coordonatori Ion Ardeleanu, Vasile Arimia, Mircea Mușat, 23 August 1944. Documente. 1944-1945,vol.III, Ed. Științifică și Enciclopedică, București, 1985, pp.99-103. Vezi și Şerban Rădulescu-Zoner, Daniela Bușe, Beatrice Marinescu, Instaurarea totalitarismului comunist în România, Ed. Cavallioti, București, 1995, p.19.

${ }^{18}$ Stelian Neagoe, op. cit., p.81.

${ }^{19}$ Stelin Neagoe, op.cit., p. 93.

${ }^{20}$ Dinu C. Giurescu, Guvernarea Nicolae Rădescu, Ed. All, București,1996, p. 35.

${ }^{21}$ Articol din Tribuna Poporului : „, Eri, cu tot timpul nefavorabil, mii de cetățeni din Galați au demonstrat în mod spontan în faţa Primăriei și Prefecturii, cerând demiterea vechiului primar și a vechiului prefect. S-a votat în unanimitate următoarea moțiune: «Noi, cetățenii oraşului Galați, reprezentând toate categoriile sociale, în frunte cu miile de muncitori de la toate întreprinderile din localitate și anume: Atelierele CFR, Uzinele Titan, șantierele Navale
} 
La 4 noiembrie, la Constanța, comuniștii, împreună cu gărzile patriotice înarmate și muncitorii din port, au schimbat prefectul, impunând pe acest post, pe unul din liderii partidului, regionalei Dobrogea, Victor Duşa. ${ }^{22}$

Pe 15 noiembrie va fi înlocuit și prefectul de Brăila, iar în zilele următoare vor fi schimbați prefecții la Brașov, Pitești, Târgoviște, Arad și Timișoara. ${ }^{23}$

$\mathrm{O}$ atenție deosebită a grupării comuniste fost dată mișcării sindicale. Controlul organizațiilor sindicale constituia atât pe plan ideologic cât și politic un aspect extrem de important. Astfel muncitorii din Ploiești, organizați în Sindicatele Unite, organizează o adunare în data de 23 octombrie 1944. Aici, luând cuvântul, muncitorul Vânătoru dezlănțuie un atac verbal virulent la adresa guvernului și în special a „hitleristului Aldea, călăul poporului român”. Participanții la adunare se transformă în demonstranți pornind încolonați pe străzile Ploieștiului cu strigăte împotriva guvernului și lozinci în favoarea liderilor din FND și, după ce se reculeg la mormântul eroului sovietic, căpitanul Karpov, din piața I. Gh. Duca, se vor deplasa la prefectura județului, unde cer înlăturarea prefectului și a primarului. Aici va ține un discurs și Gh. Radnev, liderul regionalei de partid a comuniștilor. Sindicatele Unite vor adopta și o moțiune împotriva guvernului. ${ }^{24}$

Galați, Arsenalul Maritim, muncitorii din Port, Docuri, Bazinul Nou, Uzinele Ciclop, cartierul Neptun, Fabrica Atlantic, Filatura și Țesătoria Jean Marcu, Fusul, Clearing, Brateș, Druga și celelalte întreprinderi industriale și comerciale, împreună cu populația cartierelor oraşului nostru, constatând că până azi, timp de două luni de zile, primarul Ulea, pus de guvernul demisionat, fost inspector de siguranță, nu a făcut nimic pentru combaterea speculei, pentru aprovizionarea populației nevoiașe, dovedindu-se incapabil și rău intenționat, îl considerăm demis din funcția de primar al orașului. Ca primar al orașului, noi, locuitorii din Galați alegem pe Ilie Gheorghiu, din partea Frontului Național Democratic.[...] În același mod s-a întocmit un process verbal la Prefectura județului Covurlui în Galați, prin care populația Galaților consideră demis pe fostul prefect, Gică Simionescu, numind prefect pe dr. Ursu, din partea Frontului Național Democratic, iar ca subprefect pe Maftei Nicolae din partea Frontului Plugarilor»" [Arhiva Consiliului Național pentru Studierea Arhivelor Securității (A.C.N.S.A.S.), fond Documentar, dosar nr. 20468, f. 59].

${ }^{22}$ Stelian Neagoe, op. cit., p.105.

${ }^{23}$ Ibidem, p. 123 .

${ }^{24}$ Redăm aici o parte din conținutul acestei moțiuni: „Muncitorimea din Ploiești, întrunită azi 23 Octombrie, 1944 în sala Comisiei Sindicatelor Unite, a hotărât să pornească lupta pentru răsturnarea actualului guvern, care se menține la putere în contra voinței democratice și populare. Acest guvern servește prin atitudinea lui interesele dușmanilor țării, sabotează îndeplinirea conștiincioasă a generosului armistițiu acordat poporului român de marea putere prietenă, Uniunea Sovietică și aliații ei, și ducerea războiului pentru eliberarea Ardealului, în colaborare cu glorioasa Armată Roșie Eliberatoare. Acest guvern nu arestează pe criminalii de războiu, pe toți conducătorii hitleriști și agenții Gestapoului, ci din contra, îi ajută să dispară.[...] Toate acestea sunt datorită faptului că aparatul de Stat, toate instituțiile publice şi particulare sunt pline de saboteuri, legionari şi elemente reacţionare.[...] Muncitorimea ploieșteană își ia angajamentul solemn să-și mobilizeze toate forțele și să nu dezarmeze. 
Pe lângă sindicatele muncitorești, avem de-a face și cu sindicalizarea altor categorii socio-profesionale. Astfel, în 2 decembrie 1944, are loc o adunare a funcționarilor de la Astra Română, în care se arată că ,,sindicatele nu fac politică de partid, însă sindicatele nu sunt indiferente față de politică." În altă ordine de idei, se cerea epurarea „legionarilor și a cozilor de topor.” ${ }^{25}$ De altfel, făcând referire la importanța acțiunii sindicatelor, N. Carandino făcea următoarea remarcă în Dreptatea din 22 octombrie 1944: „Mijloacele de luptă politice s-au restrâns, în esență la două, presa și strada...Partidele de extremă stângă au, datorită apelului la sindicate, o capacitate superioară în ceea ce privește mobilizarea străzii. Este un avantaj..."26

Pe 21 octombrie 1944, Lucrețiu Pătrășcanu anunța, printr-o declarație pentru Scânteia, demisia guvernului. ${ }^{27} \mathrm{La} 4$ noiembrie 1944, unul din obiectivele imediate ale comuniștilor se realizează, prin formarea unui guvern condus tot de generalul Sănătescu, în care reprezentanții FND vor avea nu mai puțin de șapte membri, și anume: Petru Groza, președintele Frontului Plugarilor, vicepreședinte al Consiliului de Miniștri, Lucrețiu Pătrășcanu, comunist, ministru de justiție, Ștefan Voitec, social-democrat, ministrul educației naționale, Gheorghe Gheorghiu Dej, comunist, ministrul telecomunicațiilor, Lothar Rădăceanu, social-democrat, ministrul muncii, și doi subsecretari de stat, respectiv, Romulus Zăroni, reprezentant al Frontului Plugarilor, la Ministerul Agriculturii și Domeniilor, precum și Teohari Georgescu, comunist, la Ministerul de Interne. ${ }^{28}$

În toată această perioadă, manifestările FND împotriva guvernului au continuat, deși, teoretic, participau la procesul guvernării. Epurarea elementelor fasciste, legionare, din toate structurile instituționale, constituia motto-ul luptei politice a comuniștilor împotriva adversarilor politici. În completare, „forțele democratice" militau permanent pentru respectarea întocmai a obligațiilor ce decurgeau din aplicarea prevederilor Convenției de Armistiţiu, față de Uniunea Sovietică.

La 2 decembrie 1944, al doilea guvern Sănătescu eșuează, acesta depunându-și demisia, iar la 6 decembrie se formează un nou guvern, condus tot de

Până când actualul guvern nu va fi izgonit și nu se va instaura la cârma țări un guvern al Frontului Naţional Democratic, singurul care poate să salveze țara de la prăpastie" (A.C.N.S.A.S., fond Documentar, dosar nr.20468, f. 11).

${ }^{25}$ Ibidem, f.8.

${ }^{26}$ Stelian Neagoe, op. cit., p.105.

${ }^{27}$ Ibidem, p. 104.

28 Ibidem, p. 119. 
un general, Nicolae Rădescu. În componența guvernului, schimbările au fost minore, raportul de forțe FND-PNL-PNȚ rămânând neschimbat. ${ }^{29}$

După consumarea atâtor evenimente în toamna anului 1944, era momentul ca Partidul Comunist din România să facă o analiza a evoluției structurale a partidului în această perioadă. Astfel, la 14 decembrie 1944, are loc ședința activului central de partid cu delegații regionalelor de partid. Se conturează situația partidului în teritoriu, relațiile $\mathrm{cu}$ celelalte formațiuni componente ale Frontului Național Democrat, sau mai bine spus modul în care acestea sunt controlate de către comunişti și relaţia cu Partidul Social Democrat, care nu se afla încă în controlul acestora. La această ședință, cea mai importantă din anul 1944 pentru comuniști, sunt prezentate rapoartele delegaților regionalelor de partid, care, în principiu, erau secretarii de partid a regionalelor, asupra stării organizațiilor locale a PCdR imediat după 23 august 1944, parcursul acestor organizații până în acel moment, situaţia grupărilor satelit (Uniunea Patriotică, Frontul Plugarilor), organizarea sindicală, relația cu membrii PSD. La ședință participă principalii lideri comuniști, Ana Pauker, Vasile Luca, Gheorghiu Dej, Teohari Georgescu, Lucrețiu Pătrășcanu și Emil Bodnăraș. ${ }^{30}$

Vom observa că numărul membrilor de partid, nu era deloc satisfăcător, nedepășind câteva sute în fiecare regională, doar în București fiind ceva mai mulți membri și anume 3000. Situația numărului mic de membri în teritoriu va fi criticată de către Ana Pauker, care sesizează că un număr mic de membri comuniști se regăsesc „tocmai în acele locuri, unde e de pildă Iașiul, Moldova, Constanța, Galați, unde au schimbat prefecții, se confiscă, se arestează, că tocmai acolo Partidul este cel mai slab, că la Constanța, unde s-au schimbat prefectul, primarul, arestezi pe cine îți place, acolo ai 200 de membri de partid". ${ }^{31} \mathrm{O}$ problemă a constituit-o și numărul foarte mic de membri ai partidului comuniste ce se regăseau imediat după 23 august 1944. Astfel, în raportul său despre regionala de partid Prahova, Gh. Radnev menționa faptul că, în momentul când a ajuns la Ploiești, pe 6 septembrie, a găsit un singur membru de partid, fără să existe vreo organizare. ${ }^{32}$ Totuși, regionala de partid Prahova (Ploiești), avea, la 6 decembrie 1944, 491 de membri de partid, cu posibilitate ca la 20 decembrie regionala de partid să ajungă la un număr de 2000 de

\footnotetext{
${ }^{29}$ Ibidem, pp.125-126.

${ }^{30}$ A.N.I.C., fond CC al PCR Cancelarie, dosar 28/1944.

${ }^{31}$ Pentru a reliefa în mod indubitabil aportul prezenței armatei sovietice, Ana Pauker va afirma în continuare: „dacă, ferească Dumnezeu, la tine la Constanța, la tine la Galați și la tine la Iași ar pleca ultimul ostaș roșu, ce ar deveni organizația de Partid de acolo și ce ar deveni toți prefecții și toți polițiștii? Și atunci, Doamne ferește, să nu vie nu un regiment ci un batalion și e vai de capul nostru”. Apoi concluzionează „Norocul nostru este că armata roșie va mai sta o bună bucată de vreme aici" (Ibidem, ff.61-62).

${ }^{32}$ Ibidem, f.13.
} 
membri. Regionala de partid Prahova cuprindea județele Prahova, Dâmbovița, și Buzău. Pe lângă școala de cadre, nou înființată, existau organizații comuniste la anumite obiective industriale: Astra, Vega, Concordia, Columbia, CFR, CTFV, Meinl. Organizarea în sindicate era un punct important pentru partid, astfel în județul Prahova erau „organizați în sindicate cu cotizație la curent” aproximativ 32000 de muncitori. Uniunea Patrioților, organizație satelit a comuniștilor, era și ea destul de bine organizată, după cum raportează tovarășul Radnev, având 85 de organizații numai în județul Prahova, și cu un număr de 2000 de membri la nivel de regională, prefectul de Prahova, Dr. Dumitriu, fiind numit din rândurile acestei organizații. Această numire va aduce după sine lipsa de ,cadre intelectuale” la UP, respectivul fiind conducătorul regionalei UP. În locul său va fi numit un muncitor, care, printre altele, se va ocupa și cu , schimbarea de primari în comunele urbane”. ${ }^{33}$

La Galați situaţia organizaţiei PCdR nu era nici ea mai bună. Conform celor relatate de către reprezentantul regional de partid Maxim, acesta a găsit o organizație constituită de către ,un vechi oportunist” care, probabil, a fost înlăturat, iar sindicatele erau conduse de muncitori legionari, care au fost și ei schimbați. Vor fi sindicalizați până la data raportului peste 5000 de muncitori dintr-un total de 14000 . În privința membrilor de partid, organizarea nu era deloc una bună. Existau totuși celule de partid în întreprinderi : celula CFR avea 25 de membri, celula Arsenalului, 8 membri, la Neptun 22 de membri iar la Titan un număr de 24. De menționat că majoritatea patronilor erau refugiați la București. Dacă la Galați era, totuși, o organizație activă, celelalte județe, anume Bârlad, Tecuci și Râmnicu Sărat, aveau organizații „foarte slabe”. În schimb, la organizația de tineret erau nu mai puțin de 600 de membri. Pe lângă prefect și primar, schimbați, după cum am văzut mai înainte, prin voința ,poporului”, tovarășul Maxim raportează liderilor de la București că a schimbat și poliția, în Galați. Pentru mediul rural, organizația de sprijin era Frontul Plugarilor, organizaţie prin care se avea în vedere înlocuirea primarilor, cu elemente agreate, sau membri ai Frontului Plugarilor. În acest sens, existau 36 de comitete ale Frontului Plugarilor - cel mai probabil doar în județul Covurlui și, ceea ce este mai important, ,primari aleși”. Din raportul tovarășului Maxim, se observă o implicare a tuturor organizațiilor Frontului Național Democrat asupra chestiunilor economice ale urbei, ale județului, de ai fi zis ca partidul, direct sau prin organizațiile satelit, deja deține control absolut asupra vieții economice din zonă. Prin urmare, în cadrul Uniunii Patrioților, se organizează comitete cetățenești pentru a lupta împotriva speculei. Totodată, Uniunea Patrioților „este mobilizată pentru ajutorarea primăriei în chestia aprovizionării”. Mai mult, Apărarea Patriotică va organiza comitete de femei pentru a împărți lapte și pâine copiilor. Partidul avea

${ }^{33}$ Ibidem, ff. 13-14. 
la Galați și un ziar, Desrobirea, „un ziar bunişor de provincie” în viziunea delegatului Maxim. Referitor la social democrați, erau patru membri ai acestui partid cu care colaborau în cadrul Frontului Unic Muncitoresc. ${ }^{34}$

La mai puțin de trei luni de la acest raport, la 2 martie1945, avem un nou raport privind ,activitatea politică și organizatorică din regionala Dunărea de Jos”, întocmit de către instructorul CC, Radnev, care, în decembrie 1944, era secretarul regionalei de partid Prahova, regionala Dunăre de Jos având în componență organizațiile Covurlui, Tecuci, Tutova, Putna, R. Sărat, Bârlad. Situația constatată de către instructorul $\mathrm{CC}$, Radnev nu era una care să corespundă cerinţelor partidului, specificându-se că „Munca a fost sectară, neexistând un plan de muncă, cu sarcini bine precizate pentru fiecare membru de partid [...] Există un comitet județean, dar făcea mai mult munca județenei, datorită slabelor legături cu celelalte județe care compun regionala.” De exemplu, organizația județeană Tecuci era „, una dintre cele mai slabe organizații, condusă de Nicolau Teodor, ,element slab”, înconjurat de „o serie de elemente putrede" care ,îl împiedică de a vedea masele organizate în sindicat" iar secretarul organizației din Râmnicu-Sărat, Călugăru Vasile, era înconjurat „de elemente mic burgheze”, „neglijând aproape cu totul elementele din fabrici”. Era necesară, prin urmare, o reorganizare a regionalei de partid, urmând ca în scurt timp, numărul membrilor de partid să crească în mod exponențial. ${ }^{35}$

Revenind la ședința din 14 decembrie 1944, avem raportul secretarului regional din Dobrogea, Cioroiu care, vizând în primul rând latura administrativă care vorbește de subordonarea „, subordonarea autorităţilor administrative și polițienești” $\mathrm{Au}$ fost puși, de către partid, prefecți în ambele județe, Constanța și Tulcea, și primari în ambele reședințe de județ, s-au operat arestări. $\mathrm{Cu}$ toate acestea, organizația județeană din Constanța avea doar 150 de membri de partid, comitetul regional fiind format din patru membri, iar cel județean din 11 membri. La Tulcea

\footnotetext{
${ }^{34}$ Ibidem, ff.7-10.

35 A.N.I.C., fond CC al PCR Cancelarie, dosar nr.146/1945, ff.1-5. În final avem și concluziile instructorului Radnev: „Cum am ajuns la Galați am convocat activul de partid și, după ședința avută, mi-am dat seama că un comitet regional real și viu nu există. Imediat, împreună cu tov. Babuci Pavel am luat măsuri pentru reorganizarea comitetului județean care de fapt făcea munca regionalei, rămânând ca după ce vom face controlul în toate județele care compun regionala să constituim și comitetul regional. Acest lucru a fost imposibil din cauză că elementele care au fost găsite aproape în toate județele nu corespund pentru această calitate. Pentru început a fost scos tov Câmpeanu de la jud Brăila și a fost adus la Galați ca secretar al regionalei. Al doilea membru din regională, ca responsabil la agitație și propagandă, a fost pus tov. Mendelsohn. Iar ca responsabil la resortul feminin Kato Wegh. Sa hotărât ca în timpul cel mai scurt regionala să scoată câțiva tovarăși din Galați și Brăila, pentru a fi trimişi ca instructori ai regionalei în toate județele - până la 23 martie organizația de partid (Dunărea de Jos) trebuie să se ridice la 8000 de membri-Galați, Brăila 2000.” (Ibidem, f. 5).
} 
comitetul județean avea 7 membri de partid, iar ca membri nu era o cifra sigură, fiind raportați 400 de membri dar nu toți fiind controlați. Bineînțeles, existau și celule pe sindicate, însumând un număr de 96 membri de partid, la CFR, SNC, DPM, Desrobirea, etc. În județul Constanța existau patru celule de partid în cadrul plășilor, la Mangalia, Ostrov, Medgidia, Constanța. Exista și o școală de cadre unde, printre altele, se discuta „despre leninism”, fiind programată o perioadă mai lungă pentru „Istoria Partidului Bolșevic Rus”, deoarece trebuia ca „toți membrii de partid să știe ce înseamnă 7 Noiembrie, învățând istoria Partidului Bolșevic. ${ }^{36}$ Totodată, făcându-se referire la organizarea sindicală, pentru Constanţa, se identifică un număr de 16 organizații sindicale, cea mai importantă fiind sindicatul de la CFR, cu 700 de membri. Organizația UTC era destul de activă, având peste 2000 de membri. ${ }^{37}$ Referitor la epurare, tovarășul Cioroiu explica faptul ca nu s-a început din cauza lipsei instrucțiunilor. În schimb, fuseseră arestați în jur de o sută de persoane și, după prima triere, au fost eliberate 23. De asemenea, la Constanța fuseseră „aleși primari și delegați ai Frontului Plugarilor. ${ }^{38}$

După 23 august 1944, la venirea tovarășului Câmpeanu la Brăila nu erau decât doi membri de partid. La momentul prezentării raportului, comitetul județean al partidului comunist avea la Brăila un număr de 28 de membri și celule de partid în toate fabricile, cu membri de partid. Membri de partid urmau a fi educaţi prin „,referate săptămânale” prin care li se explica „,e este un membru de partid, care sunt îndatoririle lui" 39

Referitor la zona Olteniei, Roșianu, reprezentantul regionalei Oltenia, spunea despre aceasta că este „un centru reacționar, e pepiniera reacționarismului din România”. Tinând cont de asta, s-au organizat comitete județene provizorii, „,cu un responsabil din partea Regionalei". Verificarea tuturor membrilor de partid a determinat ca, la 1 noiembrie 1944, să fie la Craiova, dintre muncitori, 80 de membri de partid. Regionala Olteniei cuprindea județele Dolj, Gorj, Vâlcea și Mehedinți.

O organizație de partid exista și în Ardealul de Nord, regionala fiind reprezentată de tovarășul Jakab. Regiunea era sub administrație sovietică, fiecare oraș având ", un comandant sovietic care nu se amestecă deloc în treburile interne", iar prefecții „dau ordonanțe cu putere de lege”. În regională exista un comitet regional cu cinci membri, trei fiind din Cluj, câte unul din Oradea și Târgu-Mureș, care conducea un număr de 70 de membri de partid, din care 7 erau dintre maghiarii

\footnotetext{
${ }^{36}$ A.N.I.C., fond CC al PCR, Cancelarie, dosar nr. 28/1944, f. 3.

${ }^{37}$ Ibidem, ff. 4-5.

${ }^{38}$ Ibidem, f. 5.

${ }^{39}$ Ibidem, f.11.
} 
de la MADOSZ. Organizarea sindicală era destul de importantă în Cluj, fiind 1516000 de muncitori în sindicate, adică , aproximativ 95\% din muncitorime”. ${ }^{40}$

Chiar dacă numărul membrilor de partid nu era unul spectaculos şi reprezentativitatea la nivelul județelor unde nu se afla regionala de partid era destul de modestă, cel puțin în teritoriu, comuniștii vor încerca sa dețină funcțiile de conducere în administrație, și anume prefecții care erau reprezentanții guvernului în teritoriu, şi primarii, atât din centrele importante cât şi din zonele rurale unde acționa, sub îndrumarea directă a partidului, Frontul Plugarilor, cu organizații mai în toate localităţile rurale. De asemenea, organizarea mișcării sindicale, ce avea în conducere elemente agreate de comunişti, angrenarea sindicatelor în lupta împotriva guvernului, participarea la mitinguri pe plan local sau la nivel central vor sprijini planurile comuniste de preluare as puterii. Aceste aspecte îl vor determina pe Gheorghiu Dej să afirme peste câteva luni, la ședința Biroului Politic al PCdR din 23 aprilie 1945: „La al doilea guvern nu aveam o reprezentare destul de puternică. Eram o minoritate însă obraznică, îndrăzneață, cu sprijin de afară, când era destul să lansăm un cuvânt de ordine pentru a strânge în stradă mii de cetățeni". ${ }^{41}$ În cadrul şedinței respective Ana Pauker are un discurs interesant despre situația partidului comunist de la 23 august, când remarcă următoarele: „Dacă partidul nostru ar fi fost puternic cu mult înainte de 23 august, am fi pus capăt războiului și am fi avut un guvern democratic de la început. ${ }^{42}$

Ceea ce peste câțiva ani va fi numit deviaţionism sau fracţionism, reprezenta la sfârșitul anului 1944, politica de organizare a unei formațiuni puternice care trebuia să se impună în cadrul eșichierului politic românesc, indiferent prin ce mijloace.

În această perioadă se deplasează la București un personaj care își va pune amprenta asupra ascensiunii comuniștilor români, in prim planul vieții politice și anume Andrei Ianuarevici Vâșinski, locțiitor al Comisarului Poporului pentru Afaceri Externe, al Uniunii Sovietice, oficial pentru reglementarea plății reparațiiilor de război potrivit condițiilor și interpretării Moscovei. ${ }^{43}$ Cine era Vâşinski ? Unul din artizanii marii terori staliniste din URSS, fiind procuror general al Sovietului Suprem al Uniunii Sovietice în acea perioadă, în care „din 139 de membri şi membri supleanți ai Comitetului Central în 1934, 70\%, adică 98, aveau să fie arestaţi și împuşcați până în $1938 .{ }^{44} \mathrm{Cu}$ toate acestea, Vâşinski va afirma, la începutul lui

\footnotetext{
${ }^{40}$ Ibidem, ff.29-31.

${ }^{41}$ A.N.I.C., fond CC al PCR, Cancelarie, dosar nr.30/1945,f. 8.

${ }^{42}$ Ibidem, f.3.

${ }^{43}$ Dinu C. Giurescu, op. cit., p. 42.

${ }^{44}$ Jacques de Launay, Istoria secretă a Cominternului.1919-1943, Ed. Venus, București, 1993, p.69.
} 
decembrie 1944, într-o discuție cu Mihail Ralea, că „Uniunea Sovietică nu intenționează să impună un regim comunist în România și nici nu dorește să încorporeze România în Uniunea Sovietică”, în schimb, ,întrucât România a fost ostilă și a constituit o amenințare pentru Uniunea Sovietică”, aceasta „va insista pentru o schimbare în clasele conducătoare, în așa măsură încât să ofere garanția că România a devenit un vecin cu adevărat prieten". ${ }^{45}$

Sprijinul Partidului Social Democrat pentru Frontul Național Democrat este reafirmat, la 10 ianuarie 1945, într-un comunicat al Comitetului Central al PSD, care menţionează că „susține cu fermitate poziţia Frontului Unic Muncitoresc și al FND”. Tot atunci, Frontul Plugarilor adresează un apel către țărănime în lupta ,pentru sprijinirea FND-ului" ${ }^{46}$

Pe 24 ianuarie 1945 are loc Consiliul Frontului Naţional Democrat. Luând cuvântul, Gheorghiu Dej, care în urmă cu câteva zile în urmă fusese la Moscova, ridica problema Nordului Transilvaniei, care se afla în acel moment sub administrația Armatelor Sovietice : „Că Ardealul de Nord este al României nici nu poate fi pus în discuție. Atunci, deși eliberat, de ce nu se permite nici azi întoarcerea autorităților românești?” Și rezolvarea pare să vină de la sine: „Imediat după constituirea unui guvern de Front Naţional Democrat, Ardealul de Nord va veni la corpul național, va intra practic în administrația românească și aceasta ar da satisfacție și ardelenilor și întregului popor român"47

$\mathrm{Cu}$ atât mai mult, problema Transilvaniei de Nord este atinsă într-unul din punctele Programului de Guvernare al Frontului Naţional Democrat publicat la 29 ianuarie 1945, în ziarul Scânteia, unde se făcea mențiunea că Transilvania de Nord ar fi „despărțită astăzi de restul țării din pricina politicii șovine și reacționare a elementelor fasciste din Guvernele care s-au succedat de la 23 august 1944”48

\footnotetext{
${ }^{45}$ Dinu C. Giurescu, op. cit.,p. 43.

${ }^{46}$ Stelian Neagoe, op. cit., p.159.

${ }^{47}$ Florin Constantiniu, P.C.R., Pătrăşcanu și Transilvania (1945-1946),Ed. Enciclopedică, București, 2001, p.77. În memoriul adresat de Comisarul Poporului pentru Afacerile Străine a Republicii Sovietice Federative Ruse A. I. Laurentiev către A.I, Vâşinski se spunea deschis: „Problema transmiterii Transilvaniei de Nord trebuie să devină o importantă pârghie de influenţă asupra guvernului român nu numai la capitolul îndeplinirii obligațiilor economice, prevăzute de Convenția de Armistițiu, dar și cel al politicii sale interne și externe" (Misiunile lui A.I.Vâșinski în România (Din istoria relațiilor româno-sovietice 1944-1946) .Documente secrete, Institutul Naţional pentru Studiul Totalitarismului, București, 1997, p.34).

${ }^{48}$ Scânteia, nr. 123 din 29 ianuarie 1945, în Stelian Neagoe, op.cit., p.188.
} 
Demonstrații pentru un guvern FND au fost organizate în țară, iar în București au fost mitinguri la Atelierele CFR „Grivița”, „Malaxa”, „Vulcan”, „Filatura Românească"49

Una din marile demonstrații ale Frontului Naţional Democrat a avut loc la București la 24 februarie 1945. De data aceasta, demonstranții vor recurge la violență, trăgând focuri de armă asupra sediului Ministerului de Interne, forțele de ordine ripostând. Opt dintre manifestanți au fost omorâți și s-au înregistrat, de asemenea, mai mulți răniți. Imediat după eveniment, liderii comuniști vor ține discursuri în Piaţa Palatului Regal. Lucrețiu Pătrăşcanu, ministru de justiţie în acel moment, avea să declare că: „, gloanțele trase împotriva demonstranţilor FND, dovedesc că în fruntea Guvernului se află un criminal, care nu mai trebuie să stea acolo. În momentul de faţă, fiecare dintre noi este mobilizat pentru înfăptuirea FND. Noi am plecat să demonstrăm pașnic, dar am fost întâmpinați cu focuri de arme. Suntem provocați [... Îndemnul nostru: fiecare dintre noi să se considere de astăzi înainte un soldat, pentru ca să înfăptuim prin forța noastră, a maselor populare, adevăratul Guvern al Frontului Naţional Democrat." ${ }^{\text {50 }}$

O notă de răspuns la acest miting, o va da primul ministru Rădescu la radio în seara zilei de 24 februarie: „Cei fără neam și fără Dumnezeu, așa cum i-a botezat poporul, au pornit să aprindă focul în țară și s-o înece în sânge. O mână de inși conduși de doi venetici, Ana Pauker și ungurul Luca, caută prin teroare să supună neamul. Vor cădea striviţi. [...] Sub masca democrației, democrație pe care la fiecare pas o calcă în picioare, aceste fioroase hiene nădăjduiesc să ajungă în stăpânirea țării.[...] Eu și cu armata ne vom face datoria până la capăt." ${ }^{11}$

Dar premierul Rădescu nu va mai avea timp să se răfuiască cu comuniștii Pauker și Luca, veniți de la Moscova în toamnă. Asta pentru că, probabil, sub influența ultimelor evenimente, sosește la București A.I. Vâșinski pe 27 februarie 1945. Specialistul în epurare va da lovitura decisivă asupra firavei democrații românești. Primit de către regele Mihai la Palatul Regal, Vâşinski impune regelui demiterea lui Rădescu în aceeași zi. ${ }^{52}$

Un nou miting FND are loc la 1 martie 1945, iar seara A.I. Vâşinski se deplasează din nou la palat și îi cere din nou regelui Mihai să-l desemneze pe reprezentantul FND, Petru Groza, ca prim ministru : ,Noi vrem un guvern în care să avem încredere. Un guvern în care, dacă Majestatea Voastră are încredere, să avem

\footnotetext{
${ }^{49}$ Stelian Neagoe, op. cit., p.189.

${ }^{50}$ Scânteia,nr.153 din 28 februarie 1945, în Stelian Neagoe, op. cit., pp.238-239.

${ }^{51}$ Stelian Neagoe, op. cit., pp.239-240.

${ }^{52}$ Ibidem, pp.256-257.
} 
și noi și dacă noi avem încredere, să aibă și Majestatea Voastră încredere. Cu titlu pur sugestiv eu aş recomanda pe Petru Groza." ${ }^{53}$

După o primă respingere a listei Guvernului propusă de Petru Groza și replica lui Vâșinski adresată regelui : „Anularea mandatului Groza va fi considerată de Guvernul Sovietic drept un act ostil", la 6 martie 1945 este impus pe scena politică românească guvernul condus de Petru Groza. Astfel, în câteva luni, cu sprijinul nemijlocit al Moscovei, Partidul Comunist din România ajungea la guvernare.

Totodată, dacă ținem cont de raportul lui Iosif Rangheț în cadrul ședinței cu activul centra de partid, observăm o creștere a numărului de membri comuniști destul de consistentă în primele luni ale aceluiași an. Astfel, în luna februarie partidul număra nu mai puțin de 15.000 de membri, până la 23 aprilie 42.653 de membri, iar în momentul prezentării raportului, (25-27 aprilie) să ajungă la 52.253, cu o creștere de aproape 10.000 de membri în câteva zile. ${ }^{54} \mathrm{O}$ creștere substanțială a numărului membrilor de partid s-a realizat și în București, cu 5.000 la sfârşitul lunii martie şi un număr de 13.000 la 23 aprilie $1945 .^{55}$. Problemele organizării partidului erau departe de a fi rezolvate. În regionale nu erau încă constituite sau nu funcționau resorturile organizatorice, controlul cadrelor fiind o chestiune importantă pentru partid. ${ }^{56}$ Politica de recrutare masivă de membri va continua pe tot parcursul anului 1945.

\footnotetext{
${ }^{53}$ Ibidem, pp.258-259.

${ }^{54}$ A.N.I.C., fond CC al PCR Cancelarie dosar nr.32/1945, f.16.

${ }^{55}$ Idem, dosar nr.30/1945, f. 23.

${ }^{56}$ „Noi nu cunoaștem membrii de partid, nu avem caracteristica lor, capacitatea și tăria lor. Și atunci nu numai că pătrund în partid elemente legionare și altele, dar noi nu avem de unde să cunoaştem oamenii şi, de multe ori nu ne putem ocupa și folosi de elementele cele mai bune. Neavând evidența cadrelor, nu am putut lărgi suficient partidul.” (Discursul lui Vasile Luca la Şedința cu activul central de partid din 25-27 aprilie 1945, în A.N.I.C., fond CC al PCR Cancelarie, dosar nr. 32/1945, f.17).
} 